\title{
ADRB3 wt Allele
}

National Cancer Institute

\section{Source}

National Cancer Institute. ADRB3 wt Allele. NCI Thesaurus. Code C126972.

Human ADRB3 wild-type allele is located in the vicinity of 8p11.23 and is approximately 4 $\mathrm{kb}$ in length. This allele, which encodes beta-3 adrenergic receptor protein, is involved in catecholamine-dependent $\mathrm{G}$ protein-coupled receptor signaling. Mutation and variation in the gene is associated with increased susceptibility to obesity. 